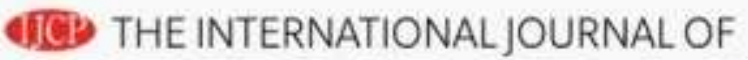 CLINICAL PRACTICE
}

\section{Lone Atrial Fibrillation: What is known and what is to come.}

\begin{tabular}{|r|l|}
\hline Journal: & International Journal of Clinical Practice \\
\hline Manuscript ID: & IJCP-10-10-0565.FT10.R1 \\
\hline Wiley - Manuscript type: & Systematic Review \\
\hline Date Submitted by the \\
Author: & 14-Nov-2010 \\
\hline Complete List of Authors: & $\begin{array}{l}\text { Potpara, Tatjana; Clinical Center of Serbia, University Cardiology } \\
\text { Clinic } \\
\text { Lip, Gregory; City Hospital, University Department of Medicine }\end{array}$ \\
\hline Specialty area: & \\
\hline \multicolumn{2}{|c}{} \\
\hline
\end{tabular}

\section{SCHOLARONE ${ }^{\text {m }}$ \\ Manuscripts}


Lone Atrial Fibrillation: What is known and what is to come.

Tatjana S. Potpara

Gregory Y. H. Lip

$\mathrm{MD}, \mathrm{PhD}^{*}$

MD, FESC, FACC

*University Cardiology Clinic, Clinical Center of Serbia, Belgrade, Serbia.

$\ddagger$ University of Birmingham Centre for Cardiovascular Sciences, City Hospital, Birmingham B18 7QH, UK.

\section{Address for correspondence:}

Prof GYH Lip. Tel +44 121 5075080; Fax: +44 121554 4083; g.y.h.lip@ bham.ac.uk

\section{Disclosures}

None. 


\section{Abstract}

Atrial fibrillation (AF) is the most prevalent sustained cardiac arrhythmia in adults, affecting $>1 \%$ of general population. AF is commonly associated with structural heart disease and is a major cause of significant cardiovascular morbidity and mortality. AF sometimes develops in a subset of young patients (e.g. aged $\leq 60$ years), with no evidence of associated cardiopulmonary or other comorbid disease (including hypertension), and has been referred to as 'lone AF'. The latter generally has a favorable prognosis; the prognostic and therapeutic implications of an accurate identification of patients with truly lone AF (that is, truly at low risk of complications), if any, would be of the utmost importance. The true prevalence of lone AF is unknown, varying between $1.6 \%$ and $30 \%$, depending on the particular study population.

Nonetheless, novel risk factors for AF, including obesity, metabolic syndrome, sleep apnea, alcohol consumption, endurance sports, anger, hostility, subclinical atherosclerosis and others, have been increasingly recognized. Also, various underlying pathophysiologic mechanisms predisposing to $\mathrm{AF}$, including increased atrial stretch, structural and electrophysiological alterations, autonomic imbalance, systemic inflammation, oxidative stress and genetic predisposition, have been proposed. The growing evidence of these diverse (and numerous) pathogenic mechanisms and factors related to AF inevitably raises the question of whether 'lone AF' does exist at all.

In this review article we summarize the current knowledge of the epidemiology, pathophysiology, clinical course and treatment of patients with so-called 'lone AF' and outline emerging insights into its pathogenesis and the potential therapeutic implications of a diagnosis of lone AF. 


\section{Review criteria}

We searched MEDLINE (1950 through October 2010) and Google Scholar using the terms "lone atrial fibrillation", "lone atrial fibrillation epidemiology", "natural history of lone atrial fibrillation" and "lone atrial fibrillation what do we know" and manually reviewed the references in English language. Abstracts from international cardiovascular meetings were studied to identify unpublished data.

\section{Message for the clinic}

The patients diagnosed as so-called 'lone AF' comprise a heterogeneous group and should not $a$ priori be classified as having a benign rhythm disorder. Detailed assessment of lone AF patients is warranted, both at presentation and regularly during follow-up. Emerging risk factors and pathophysiologic mechanisms predisposing to AF should also be considered and, clearly, there is a need for further research regarding stroke risk stratification and optimal antiarrhythmic treatment in these patients, including 'old' and new investigational antiarrhythmic drugs and catheter ablation of AF. 


\section{Introduction}

Atrial fibrillation (AF) is the most prevalent sustained cardiac arrhythmia in adults, affecting $>1 \%$ of general population. The incidence of AF is projected to rise over the next few decades and AF has therefore been referred to as a "non-contagious epidemic" [1-5].

$\mathrm{AF}$ is associated with significant cardiovascular morbidity and mortality, primarily due to ischemic stroke, congestive heart failure $(\mathrm{CHF})$ and impaired quality of life, with the requirement for chronic use of medication [6-11]. Well-defined risk factors for AF include advanced age, hypertension, structural heart disease, CHF, diabetes mellitus and thyroid disease $[12,13]$. In turn, the risk of AF-related complications is strongly influenced by the nature and extent of underlying co-morbid disease and age $[9,13,14]$.

AF sometimes develops in a subset of young patients (e.g. aged $\leq 60$ years), with no evidence of associated cardiopulmonary or other comorbid disease (including hypertension), and has been referred to as 'lone AF', which generally has a favorable prognosis [15-23]. The term "lone" AF was introduced $\sim 60$ years ago and it is still a diagnosis of exclusion, which should be made only after careful assessment including detailed medical history, physical examination, laboratory testing with thyroid status, electrocardiogram, echocardiography and, possibly, chest x-ray and exercise testing [15,24].

Nonetheless, novel risk factors for AF, including obesity [25-28], metabolic syndrome [29,30], sleep apnea [31-35], increased alcohol consumption [36-41], endurance sport practice [42-46], increased pulse pressure [47], anger and hostility [48,49], subclinical atherosclerosis [50,51] and others, are increasingly recognized. Also, various underlying pathophysiologic mechanisms predisposing to $\mathrm{AF}$, including increased atrial stretch, structural and electrophysiological alterations, autonomic imbalance, systemic inflammation, oxidative stress and genetic predisposition, have been proposed [52-56]. The growing evidence of these diverse (and numerous) pathogenic mechanisms and factors related to AF inevitably raises the question of whether lone AF does exist at all [57,58]. The prognostic and therapeutic implications of an 
accurate identification of patients with truly lone AF (that is, truly at low risk of complications), if any, would be of the utmost importance [59].

In this review article we summarize the current knowledge of the epidemiology, pathophysiology, clinical course and treatment of patients with so-called 'lone AF' and outline emerging insights into its pathogenesis and the potential therapeutic implications of making a diagnosis of 'lone AF'.

\section{Epidemiology of lone AF}

The overall prevalence of AF increases with age: $<1 \%$ of individuals younger than 60 and $~ 10 \%$ of those $>80$ years old have AF [3]. The true prevalence of lone AF is unknown, varying between $1.6 \%$ and $30 \%$, depending on the patients' age and criteria used in the study [16$18,20,60]$.

The lifetime risk for development of AF, in subjects aged above 40, is 1:4 both for males and females [61]. Nevertheless, males have a higher incidence of AF in all age groups. Indeed, AF develops in males at 1.5-fold greater rate than the rate in females, when adjusted for other risk factors $[12,62]$. There is a male preponderance in lone AF, with a male-to-female ratio of 3-4:1 $[16,17,20]$. However, male predominance is less evident among confirmed familial AF probands or affected relatives, when compared with nonfamilial (sporadic) lone AF patients [63]. To explain the increased frequency of sporadic lone AF in males, the possibility of an unrecognized $\mathrm{X}$-linked recessive AF in males with negative family history and apparently sporadic AF (and mothers and sisters as the healthy carriers) has been raised [63]. Of note, familial and sporadic lone AF share similar phenotypes and are clinically indistinguishable [63].

A genetic contribution to AF was recognized nearly 70 years ago, when Wolff documented an autosomal dominant transmission of lone AF in one family [64]. Since then, the familial aggregation of lone AF has been increasingly reported and certain genetic mutations (often confined to the particular family, and not found outside the family) have been described [56,65- 
73]. The heritability of AF in the general population has been documented in several populationbased studies [74-77]. For example, in the Framingham Study, parental AF increased the risk for offspring AF with an Odds Ratio of 3.2 (95\%CI: 1.7-5,9, p<0.01), when the sample was limited to those age $<75$ years old without antecedent cardiovascular morbidity [74].

In the past decade, an increasing number of genetic loci and causal mutations of genes (primarily those encoding components of potassium, sodium and L-type calcium ion channels) have been identified in lone AF patients, and significant overlap of AF with congenital long QT, short QT and Brugada syndrome, and with dilated cardiomyopathy has been observed (Table 1) [56,6583]. However, large-scale sequencing in lone AF cohorts suggests that these channel mutations are not a major cause of AF [56,83].

Nevertheless, patients at comparable risk for AF often do not exhibit uniform susceptibility to the arrhythmia, which could possibly be attributed to a genetically determined "AF diathesis" $[56,83,84]$. The introduction of genome-wide association studies, which compare non-familial AF cases to age-related and gender-matched controls, has enabled some insight into the genetics of acquired AF, and several common gene or single nucleotide polymorphisms including those encoding the renin-angiotensin-aldosterone system (RAAS), calcium handling, neurohumoral and lipoprotein pathways, gap junction proteins, ion channels, interleukins, signaling molecules and mediators of other molecular pathways have been examined [56,83,84]. However, common polymorphisms identified thus far perhaps explain only $<10 \%$ of the inherited contribution to AF [83-86].

To date, genetic studies have revealed diverse mechanisms of susceptibility to AF (Table 1). Single-gene disorders provide an insight into the electrophysiological mechanisms which predispose to AF, but it is very likely that vulnerability to AF primarily arises from the influence of multiple genes which, either alone or in combination, alter the atrial structural and functional properties. The recognition of those genes and further insight into their effect on atrial electrophysiology could facilitate the implementation of a pharmacogenomic treatment approach for treatment of AF in the future [56]. 


\section{Pathophysiology and pathogenesis of lone AF}

The occurrence of AF requires a trigger and appropriate atrial substrate to sustain reentry of electrical impulses. Various triggers can create propagating wavelets, which may lead to reentrant circuits and $\mathrm{AF}$ in the presence of functionally and structurally altered atrial myocardium (Figure 1) [87,88]. The electrophysiological hallmarks of an atrial pro-fibrillatory state are a reduced atrial effective refractory period (ERP), attenuated ERP rate adaptation and reduced impulse conduction velocity [87].

The condition of the atrial substrate is strongly influenced by the underlying disease process and ageing. Furthermore, AF itself initiates the complex processes of atrial electrical, contractile and structural remodeling, which further contributes to the AF persistence and progression (that is, "AF begets AF") (Table 1) [52,89]. Such atrial electrical and contractile remodeling occurs rapidly (within hours and days) and is reversible, whilst structural changes occur after weeks or months of persistent AF and are usually irreversible [52]. Thus, the early restoration of sinus rhythm (SR) should, at least theoretically, prevent further progression of AF. Unfortunately, a large body of evidence suggests that "SR does not beget SR" and that, in fact, vulnerability to $\mathrm{AF}$ and the risk of AF perpetuation and stability often extend beyond the time course of electrical remodeling reversal, which led to the hypothesis that "a second factor" (that is, some structural changes) is responsible for AF recurrence [90,91].

In the setting of lone AF, whereby structural disease is absent by definition, AF may be viewed as a primary electrophysiological disorder with ectopic focal discharges from the pulmonary veins and posterior wall of the left atrium playing an important role in both the initiation and maintenance of AF $[88,92,93]$. However, atrial fibrosis and loss of muscle mass have been observed in lone AF patients, along with isolated atrial myocardial perfusion abnormalities and coronary flow reserve impairment indicative of microvascular dysfunction [94,95]. For example, in a recent study of 25 patients with paroxysmal lone AF, bi-atrial abnormalities remote from arrhythmia (and thus very unlikely to result from AF-induced remodeling) were documented, including conduction abnormalities, structural changes and sinus node dysfunction [96]. More 
recently, one study of 58 lone AF patients also documented distinct abnormalities in atrial electrophysiological properties [97].

After the initial description of isolated atrial structural changes consistent with myocarditis in lone AF patients [94], many studies have documented a relationship between circulating markers of inflammation (including C-reactive protein and interleukins) and AF. Indeed, inflammation plays a significant role in the initiation and perpetuation of AF and the AF-related prothrombotic state [53,98-100]. Inflammatory biomarkers are associated with future development, recurrence and burden of AF and the likelihood of successful cardioversion [101-105]. However, inflammation may be associated not with AF per se, but rather with underlying cardiovascular disease [106]. Whether the initiation of AF activates direct inflammatory reactions or the presence of pre-existing inflammation promotes AF is not completely clarified, and both mechanisms may be operating. For example, rapid atrial activation accompanied with calcium accumulation may result in calcium overload and apoptotic loss of atrial myocytes, with the consequent low-grade inflammatory response as a part of structural remodeling [107]. Alternatively, in patients with triggering atrial foci, systemic inflammation with increased circulating C-reactive protein may predispose to AF via the classic complement pathway activation and atrial tissue damage, or by binding to phosphocholine which may contribute to membrane dysfunction by the alterations in sodium and calcium handling [98].

Other potential biomarkers of a predisposition to apparently lone AF have also been described. Atrial natriuretic peptide (ANP) and brain natriuretic peptide (BNP) are sensitive biomarkers of cardiac contractile dysfunction, and both peptides are elevated in AF patients with underlying structural heart disease [108]. In lone AF patients, a discordant pattern of elevated N-terminalpro-BNP and normal N-terminal-pro-ANP levels can be observed, but the precise mechanism of ANP and BNP uncoupling is not clarified [109]. The question of whether the increased BNP levels are the result of AF or simply a sign of subclinical cardiac alterations which predispose to AF still remains unanswered.

Apelin is an endogenous peptide hormone, which is normally involved in the counter-regulation of the angiotensin and vasopressin systems. A significant reduction of mean apelin levels has 
been found in patients with lone $\mathrm{AF}$, indicating certain alterations of the cardiac humoral axis [110].

Variations in autonomic nervous system tone are also involved in AF. Sympathetic stimulation often initiates AF in patients with structural heart disease, whilst lone AF patients more frequently have paroxysmal AF in the setting of increased vagal tone [87,111]. Although both sympathetic and parasympathetic components play a role in $\mathrm{AF}$, the cholinergic component appears to be important for spontaneous initiation of $\mathrm{AF}$; in the experimental setting, for example, electrical stimulation of the left atrial ganglionic plexi or the autonomic nerve endings with retrograde activation of the ganglia induces spontaneous firing from pulmonary veins followed by AF [112].

\section{Ultrastructural alterations and cellular electrophysiology in lone AF}

A decreased duration of action potential (AP), depressed AP plateau and attenuated response of AP duration to depolarization rate are the principal electrophysiological findings at the atrial cellular level $[113,114]$. These alterations are mediated through changes in sodium, potassium and calcium channels, which are not likely to be the principal cause of AF, but rather a nonspecific response to variety of stresses such as an altered oxidative state in the setting of increased metabolic demand, elevated sympathetic tone and increased levels of circulating cytokines. The redox state and metabolic reserve are also age-dependent, and regulation of channels is largely genetically determined [87].

Connexins are protein subunits of gap junctions - the clusters of transmembrane channels that link adjacent cells and mediate cell-to-cell electrical coupling and communication. Decreased numbers and altered spatial arrangement of connexin40 in AF have been documented, both in the atrial myocardium and thoracic veins [115-117]. These findings correlate with facilitated trigger activity in the pulmonary veins and discontinuous and slowed conduction due to intercellular uncoupling in the atrial myocardium [118,119]. In addition, connexin40 gene mutations or polymorphisms underlie an inherited predisposition to AF [82]. 
Atrial ultrastructural changes in AF patients are identified at the level of cardiomyocytes and extracellular matrix. Whilst fibrosis and myocyte degeneration could be attributed to the underlying structural disease, AF itself induces de-differentiation of cardiomyocytes and regression toward a more immature developmental stage with depleted contractile apparatus and fetal actin and myosin forms [55,87]. Apoptotic cell death is also more pronounced in the fibrillating atria [55]. An increased accumulation of various proteins in the extracellular matrix, including collagen, fibronectin-1 and fibrillin-1, has also been documented, along with the upregulation of matrix metalloproteinases, transforming growth factor $\beta 1$ and AT-1 angiotensin II receptor $[52,55,87]$. These changes may significantly alter the atrial micro-architecture (which is already complex under normal conditions) and increase vulnerability to AF in the setting of an acute stretch, which promptly activates the immediate gene program for cell hypertrophy, augments the synthesis of angiotensin II, influences the stretch-activated and other ion channels, receptors and enzymes with cytoskeletal connections, thus creating a fertile electrophysiological and anatomical environment for initiation and propagation of AF [87]. Reduced calcium systolic release and myolysis underlie contractile remodeling, which could trigger thrombus formation and atrial dilatation [120].

\section{Risk factors for lone $\mathrm{AF}$}

Apart from the traditional AF risk factors, there are numerous conditions which have been associated with AF in apparently healthy individuals.

Independent of other cardiovascular risk factors, obesity confers an increased risk of new-onset AF (3\%-8\% with each unit of increase in body mass index), which has been attributed to diastolic dysfunction due to myocardial thickening, elevated plasma volume and increased neurohormonal activation resulting in left atrial dilatation [25-27]. Lone AF patients have also been reported to be taller and leaner than other AF patients [28]. 
Obstructive sleep apnea may cause various hemodynamic alterations and autonomic imbalance predisposing to AF, and, conversely, a paroxysm of AF may result in central sleep apnea caused by an acute decrease in the left ventricular function accompanied by an increase in pulmonary wedge pressure and consequent stimulation of pulmonary vagal receptors [31-35].

A "holiday heart syndrome" of paroxysmal AF after occasional excessive alcohol intake was described over 30 years ago. Alcohol has a direct toxic effect on cardiomyocytes, causes a hyperadrenergic state with impaired vagal tone and may increase the intra-atrial conduction time. However, moderate alcohol intake (2-3 drinks/week) was not related to the increased risk of AF in the Cardiovascular Health Study [36-41]. Other stimulants including caffeine and nicotine have also been associated with AF [57].

In contrast to mild regular exercise, endurance sport practice is associated with a higher prevalence of $\mathrm{AF}$, and $>1500$ lifetime hours of practice seems to be the threshold for the association. Enlargement of the cardiac chambers, an increase in left ventricular mass and left atrial dilatation, along with increased vagal tone resulting in bradycardia and shortening of the atrial ERP, transient hypovolaemia and changes in electrolytes due to sweating have been proposed to explain the vulnerability to AF in sportsmen. There is also anecdotal evidence of AF development after the use of anabolic steroids, and changes in the autonomic function and the baro-reflex could be the underlying mechanism [42-46,57].

Various social characteristics, including the type of personality, anger and hostility and acute life stress have been shown to increase the vulnerability to AF $[48,49]$. Drug-induced AF should be considered when inotropic agents (dopamine), cholinergics (acetylcholine), adenosine, broncodilatators (especially sympathicomimetic inhalants), corticosteroids, cytostatics, central nervous system drugs (anticholinergics, dopamine agonists, antidepressants, antipsychotics, anaestetics) and others are administered [121].

Finally, what seems to be apparently 'lone AF' may occur in the setting of subclinical atherosclerosis (determined by carotid intima-media thickness and/or mitral annular calcification 
[MAC]). In the Framingham Study, for example, MAC was an independent predictor for incident AF (hazard ratio 1.6, 95\% CI: 1.1-2.2) [50,51].

\section{Clinical course of lone AF}

In some studies, lone AF patients may have a similar risk of thromboembolism, $\mathrm{CHF}$ and mortality as the general population $[17,21,22]$. However, other studies suggest otherwise. For example, in the Paris Prospective Study I, lone AF was associated with increased mortality in middle aged working men [16,23]. Also, ageing and development of underlying heart disease strongly influence the long-term prognosis of (what was originally) lone AF [14,21]. Therefore, regular follow-up with evaluation of cardiovascular risk factors is necessary in patients diagnosed as 'lone AF'. This is supported by the observation that as many as $44 \%$ of apparently lone AF patients may actually have occult arterial hypertension [122].

Patients originally diagnosed with lone AF may follow divergent clinical courses based on the left atrial volume. In contrast to those with normal atria, patients with increased left atrial volume (either at diagnosis or during the follow-up) subsequently experienced adverse cardiovascular events including stroke, which occurred at left atrial volumes $>32 \mathrm{~mL} / \mathrm{m}^{2}[123]$.

It has also been suggested that paroxysmal lone AF carries a better prognosis than chronic lone AF, regarding thromboembolism and mortality [20]. The vast majority of lone AF patients present with paroxysmal arrhythmia and have a relatively low rate of progression to permanent AF during the follow-up, with an estimated risk of progression of approximately $30 \%$ over 30 years, being significantly influenced by ageing and development of comorbidities [21]. Clinical AF types are summarized in Figure 2.

\section{Management of lone AF}


The principal aims of AF treatment are to reduce symptoms and to prevent AF-related complications, using antithrombotic therapy, ventricular rate control and treatment of concomitant cardiovascular risk factors and/or comorbidities. Symptom relief may additionally require rhythm control including cardioversion(s), long-term use of antiarrhythmic drugs and/or catheter-ablation (Figure 3) [124].

Stroke and thromboembolism is a severe complication of AF. More recently, greater efforts have been directed towards the identification of "truly low risk" AF patients who are at low risk of stroke and, therefore, do not need any antithrombotic therapy; all other patients with $\geq 1$ stroke risk factors merit oral anticoagulation therapy (Figure 3) [59]. This approach is acknowledged in the latest 2010 European Society of Cardiology Guidelines for AF [124].

The cumulative risk of stroke is very low in true 'lone AF' patients (1.3\% over 15 years) and no therapy (or aspirin) is advised [21,124]. Of note, the thromboprophylactic effect of aspirin in lone AF patients is questionable. In the Japan AF Stroke trial, aspirin150-200mg daily was worse than no therapy (the annual incidence of primary outcomes was $3.1 \%$ vs. $2.4 \%$, respectively), and the use of aspirin was associated with non-significant increased risk of major bleeds (1.6\% with aspirin vs. $0.4 \%$ in the control group) [125]. Meta-analysis of 7 trials comparing aspirin with placebo in AF patients showed a non-significant 19\%-reduction in stroke incidence (95\%CI $-1 \%$ to $35 \%$ ), which could easily be attributed to an effect of aspirin on atherosclerosis and atherothrombosis [126].

Dedicated re-assessment of thromboembolic risk factors during regular follow-ups is mandatory in lone AF patients, since the stroke risk increases with ageing or development of comorbidities (including hypertension). However, various atrial ultrastructural changes, contractile dysfunction and endothelial perturbation have been documented in apparently lone AF [101-105,108$110,120,127]$. With growing insights into these alterations, all of which could influence the stroke risk, and increasing number of potentially useful biomarkers, further refinement of thromboembolic risk assessment should be expected. 
Moreover, new oral anticoagulants are being developed for stroke prevention in AF. Those are the oral direct thrombin inhibitors (dabigatran etexilate, AZD0837) and oral factor Xa inhibitors (rivaroxaban, apixaban, endoxaban, betrixaban, YM150 and others). In contrast to the oral vitamin-K-antagonists (VKA), such as warfarin, these new agents have a rapid onset of action, a low propensity for food and drug interactions and a predictable anticoagulant effect after fixeddose administration and coagulation monitoring is unnecessary. The efficacy and safety of dabigatran compared with warfarin for the prevention of stroke and systemic embolism in AF patients was investigated in the Randomized Evaluation of Long-term anticoagulant therapy with dabigatran etexilate (RE-LY) trial [128]. The Apixaban VERsus acetylsalicylic acid to pRevent strOkES (AVERROES) study was stopped early because of clearly evident superiority of apixaban 5mg bid over aspirin in patients intolerant of or unsuitable for VKA, with similar rates of major bleeding with aspirin and the oral anticoagulant, and aspirin was less well tolerated [124].

Rhythm control may be particularly successful in patients with paroxysmal lone AF, primarily due to a relatively low propensity to $\mathrm{AF}$ progression, and various strategies could be implemented including no therapy, a "pill-in-the-pocket" strategy or long-term use of antiarrhythmic drugs (Figure 3). In general, available antiarrhythmic drugs may not be particularly effective in acute cardioversion of AF, and are only moderately successful in longterm rhythm control. Should B-blockers be ineffective, flecainide, propafenone, sotalol or dronedarone could be tried. Although amiodarone has a superior efficacy compared with other antiarrhythmic drugs, it should be reserved as an alternative because of its potential toxicity with long-term use [124,129]. Catheter ablation may be applied in symptomatic lone AF patients in whom antiarrhythmic drugs were not effective or at patient's preference [124]. Ablation strategies clearly offer better rhythm control during the short-term follow-up, but late AF recurrences are not uncommon [130-132]. Classic surgical 'maze procedure' and pulmonary vein isolation are highly effective in rhythm control, but novel procedures including thoracoscopic access and video assistance are promising [124,133,134].

Most of the currently available antiarrhythmic drugs exert their anti-AF effects via inhibition of cardiac ion channels, at the expense of an increased risk of life-threatening ventricular 
arrhythmias, worsening of left ventricular systolic dysfunction or organotoxicity [135]. Until recently, large clinical trials evaluating the ability of antiarrhythmic drugs to improve all-cause mortality have yielded neutral outcomes at best [120,135]. However, there appears to be significant reduction in both cardiovascular morbidity and mortality in AF patients treated with dronedarone, which has encouraged an essential change of focus of rhythm control management $[129,136]$. Nevertheless, there was no significant reduction in the all-cause mortality in AF patients treated with dronedarone [136]. In the prevention of recurrent AF, dronedarone is better than placebo [137] and less successful, but with significantly fewer adverse effects, compared with amiodarone [129]. However, the use of dronedarone is not safe in patients with significantly reduced left ventricular systolic function (ejection fraction $\leq 35 \%$ ), in whom dronedarone has been shown to increase mortality, predominantly due to cardiovascular causes (most notably CHF) [138].

Novel pharmacological investigational approaches to rhythm control in AF include atrialselective multiple ion channel blockers which are expected to reduce the risk of ventricular arrhythmias (vernakalant, ranolazine, AVE0118, GsMTx4, tertiapin-Q, NIP-141, NIP-142, etc), improved derivatives of existing drugs (AZD1305, AVE1231, SSR149744C, ATI2042), gap junction modifiers (rotigaptide, AAP10, GAP-134, etc), and upstream therapy, which targets arrhythmogenic structural remodeling in the atria and/or factors that promote such remodeling including hypertension, heart failure and inflammation (angiotensin-converting enzyme inhibitors [ACEIs], angiotensin receptor blockers [ARBs], statins and omega-3 polyunsaturated fatty acids [PUFAs]) [120,124,135]. Vernakalant hydrochloride is a relatively atrial-selective, early-activating $\mathrm{K}^{+}$and frequency-dependent $\mathrm{Na}^{+}$channel blocker with a half-life of 2 to 3 hours. In a randomized clinical trial, vernakalant demonstrated rapid conversion of short-duration AF compared with placebo and was well tolerated [139].

Upstream therapy could prevent the development of AF (primary prevention) or recurrence and progression to permanent AF (secondary prevention). At present, upstream therapies are not recommended for primary prevention of AF in patients without cardiovascular disease [124]. However, the use of ACEIs and ARBs may be considered in patients with recurrent AF who are taking antiarrhythmic drug therapy. There is good experimental evidence of antifibrillatory and 
antifibrotic effects of these drugs in AF patients, but the results of clinical studies are conflicting [124,140,141]. In animal models of AF, statins attenuate atrial electrical and structural remodeling and reduced inducibility of AF. However, clinical evidence in support of using statins in the secondary AF prevention, except for post-operative AF, is insufficient [124, $142,143]$.

\section{Conclusions}

Accumulating insights into the pathogenesis of apparently lone AF suggest that the entity comprises heterogeneous subsets of AF patients who should not a priori be classified as having a benign rhythm disorder. Growing evidence of numerous common variations within the genome and atrial ultrastructural alterations that predispose to AF makes the classification of $\mathrm{AF}$ as secondary to structural disease or as a 'lone' arrhythmia increasingly meaningless. Detailed assessment of lone AF patients is warranted, both at presentation and regularly during the follow-up. Emerging risk factors and pathophysiological mechanisms predisposing to AF should also be considered and, clearly, there is a need for further research regarding stroke risk stratification and proper antiarrhythmic drug treatment in so-called lone AF patients.

\section{Funding and Acknowledgements}

None. 


\section{References}

1. Heeringa J, van der Kuip DAM, Hofman A, Kors JA, van Herpen G, Stricker BHC, Stijnen T, Lip GYH, Witteman JCM. Prevalence, incidence and lifetime risk of atrial fibrillation: the Rotterdam study. Eur Heart J 2006;27:949-953.

2. Stewart S, Hart CL, Hole DJ, McMurray JJ. Population prevalence, incidence, and predictors of atrial fibrillation in the Renfrew/Paisley study. Heart 2001;86:516-521.

3. Go AS, Hylek EM, Phillips KA, Chang Y, Henault LE, Selby JV, Singer DE. Prevalence of diagnosed atrial fibrillation in adults: national implications for rhythm management and stroke prevention: the AnTicoagulation and Risk Factors in Atrial Fibrillation (ATRIA) Study. JAMA 2001;285:2370-2375.

4. Furberg CD, Psaty BM, Manolio TA, Gardin JM, Smith VE, Rautaharju PM. Prevalence of atrial fibrillation in elderly subjects (the Cardiovascular Health Study). Am J Cardiol 1994;74:236-41.

5. Braunwald E. Shattuck Lecture. Cardiovascular medicine at the turn of the millennium: triumphs, concerns, and opportunities. N Engl J Med 1997;337:1360.

6. Benjamin EJ, Wolf PA, D’Agostino RB, Silbershatz H, Kannel WB, Levy D. Impact of atrial fibrillation on the risk of death: The Framingham heart study. Circulation 1998;98:946-952.

7. Wolf PA, Abbott RD, Kannel WB. Atrial fibrillation as an independent risk factor for stroke: the Framingham Study. Stroke 1991;22:983-988.

8. Menke J, Lüthje L, Kastrup A, Larsen J. Thromboembolism in atrial fibrillation. Am J Cardiol 2010; 105:502-10.

9. Chugh SS, Blackshear JL, Shen WK, Hammil SC, Gersh BJ. Epidemiology and natural history of atrial fibrillation: clinical implications. J Am Coll Cardiol 2001;37:371-78.

10. Wang TJ, Larson MG, Levy D, Benjamin EJ, Corey D, Leip EP, Vasan RS. Temporal relations of atrial fibrillation and congestive heart failure and their joint influence on mortality: the Framingham Heart Study. Circulation 2003;107:2920-5.

11. Savelieva I, Camm AJ. Atrial fibrillation and heart failure: natural history and pharmacological treatment. Europace 2004;5:S5-S19.

12. Benjamin EJ, Levy D, Vaziri SM, D’Agostino RB, Belanger AJ, Wolf PA. Independent risk factors for atrial fibrillation in a population-based cohort. The Framingham Heart Study. JAMA 1994;271:840-844.

13. Ryder KM, Benjamin EJ. Epidemiology and significance of atrial fibrillation. Am $\mathbf{J}$ Cardiol 1999;84:131R-138R.

14. Kopecky SL, Gersh BJ, McGoon MD, Chu CP, Ilstrup DM, Chesebro JH, Whisnant JP. Lone atrial fibrillation in elderly persons. A marker for cardiovascular risk. Arch Intern Med 1999;159:1118-22.

15. Fuster V, Ryden LE, Cannom DS, Crijns HJ, Curtis AB, Ellenbogen KA, Halperin JL, Le Heuzey J-Y, Kay GN, Lowe JE, Olsson SB, Prystowsky EN, Tamargo JL, Wann S, Smith SC, Jacobs AK, Adams CD, Anderson JL, Antman EM, Hunt SA, Nishimura R, Ornato JP, Page RL, Riegel B, Priori SG, Blanc J-J, Budaj A, Camm AJ, Dean V, Deckers JW, Despres C, Dickstein K, Lekakis J, McGregor K, Metra M, Morais J, Osterspey A, Zamorano JL. ACC/AHA/ESC 2006 guidelines for the management of 
patients with atrial fibrillation: a report of the American College of Cardiology / American Heart Association Task Force on Practice Guidelines and the European Society of Cardiology Committee for Practice Guidelines (Writing Committee to Revise the 2001 Guidelines for the Management of Patients With Atrial Fibrillation). Eur Heart J 2006; 27:1979-2030.

16. Brand FN, Abbott RD, Kannel WB, Wolf PA. Characteristics and prognosis of lone atrial fibrillation. 30-year follow-up in the Framingham Study. JAMA 1985;254:3449-3453.

17. Kopecky SL, Gersh BJ, McGoon MD, Whisnant JP, Holmes DR, Ilstrup DM, Frye RL. The natural history of lone atrial fibrillation. A population-based study over three decades. N Engl J Med 1987;317:669-674.

18. Davidson E, Rotenberg Z, Weinberger I, Fuchs J, Agmon J. Diagnosis and characteristics of lone atrial fibrillation. Chest 1989;95:1048-1050.

19. Rostagno C, Bacci F, Martelli M, Naldoni A, Bertini G, Gensini GF. Clinical course of lone atrial fibrillation since first symptomatic arrhythmic episode. Am J Cardiol 1995;76:837-839.

20. Scardi S, Mazzone C, Pandullo C, Goldstein D, Poletti A, Humar F. Lone atrial fibrillation: prognostic differences between paroxysmal and chronic forms after 10 years of follow-up. Am Heart J 1999;137:686-91.

21. Jahangir A, Lee V, Friedman PA, Trusty JM, Hodge DO, Kopecky SL, Packer DL, Hammill SC, Shen WK, Gersh BJ. Long-term progression and outcomes with aging in patients with lone atrial fibrillation. A 30-year follow-up study. Circulation 2007;115:3050-56.

22. Potpara T, Grujic M, Marinkovic J, Vujisic-Tesic B, Ostojic M, Polovina M. Mortality of patients with lone and idiopathic atrial fibrillation is similar to mortality in general population of Serbia. Vojnosanit Pregl 2010;67:132-135.

23. Jouven $\mathrm{X}$, Desnos $\mathrm{M}$, Guerot $\mathrm{C}$, Ducimetiere $\mathrm{P}$. Idiopathic atrial fibrillation as a risk factor for mortality. Eur Heart J 1999;20:896-899.

24. Evans W, Swann P. Lone auricular fibrillation. Br Heart J 1954;16:189-194.

25. Wang TJ, Parise H, Levy D, D’Agostino RB, Wolf PA, Vasan RS, Benjamin EJ. Obesity and the risk of new-onset atrial fibrillation. JAMA 2004;292:2471-2477.

26. Frost L, Hune LJ, Vestergaard P. Overweight and obesity as risk factors for atrial fibrillation or flutter: the Danish diet, cancer, and health study. Am J Med 2005;118:489495.

27. Dublin S, French B, Glazer NL, Wiggins KL, Lumley T, Psaty BM, Smith NL, Heckbert SR. Risk of new-onset atrial fibrillation in relation to body-mass index. Arch Intern Med 2006;166:2322-2328.

28. Wanahita N, Messerli FH, Bangalore S, Gami AS, Somers VK, Steinberg JS. Atrial fibrillation and obesity - results of a meta-analysis. Am Heart J 2008;155:310-315.

29. Watanabe H, Tanabe N, Watanabe T, Darbar D, Roden DM, Sasaki S, Aizawa Y. Metabolic syndrome and risk of development of atrial fibrillation. The Niigata Preventive Medicine Study. Circulation 2008;117:1255-1260.

30. Chamberlain AM, Agarwal SK, Ambrose M, Folsom AR, Soliman EZ, Alonso A. Metabolic syndrome and incidence of atrial fibrillation among blacks and whites in the Atherosclerotic Risk in Communities (ARIC) Study. Am Heart J 2010;159:850-856.

31. Roche F, Xuong AN, Court-Fortune I, Costes F, Pichot V, Duverney D, Vergnon JM, Gaspoz JM, Barthelemy JC. Relationship among the severity of sleep apnea syndrome, 
cardiac arrhythmias, and autonomic imbalance. Pacing Clin Electrophysiol 2003;26:669677.

32. Porthan KM, Melin JH, Kupila JT, Venho KK, Partinen MM. Prevalence of sleep apnea syndrome in lone atrial fibrillation: a case-control study. Chest 2004;125:879-885.

33. Kanagala R, Murali NS, Friedman PA, Ammash HM, Gersh BJ, Ballman KV, Shamsuzzaman AS, Somers VK. Obstructive sleep apnea and the recurrence of atrial fibrillation. Circulation 2003;107:2589-2594.

34. Gami AS, Hodge DO, Herges RM, Olson EJ, Nykodim J, Kara T, Somers VK. Obstructive sleep apnea, obesity and the risk of incident atrial fibrillation. J Am Coll Cardiol 2007;49:565-571.

35. Rupprecht S, Hutschenreuther J, Brehm B, Figulla HR, Witte OW, Schwab M. Causality in the relationship between central sleep apnea and paroxysmal atrial fibrillation. Sleep Med 2008;9:462-464.

36. Ettinger PO, Wu CF, De La Cruz C Jr, Weisse AB, Ahmed SS, Regan TJ. Arrhythmias and the "Holiday Heart": alcohol-associated cardiac rhythm disorders. Am Heart J 1978;95:555-562.

37. Koksinen P, Kupari M, Leinonen H, Luomanmaki K. Alcohol and new onset atrial fibrillation: a case-control study of a current series. Br Heart J 1987;57:468-473.

38. Djousse L, Levy D, Benjamin EJ, Blease SJ, Russ A, Larson MG, Massaro JM, D'Agostino RB, Wolf PA, Ellison RC. Long-term alcohol consumption and the risk of atrial fibrillation in the Framingham Study. Am J Cardiol 2004;93:710-713.

39. Frost L, Vestergaard P. Alcohol and risk of atrial fibrillation or flutter: a cohort study. Arch Intern Med 2004;164:1993-1998.

40. Mukamal KJ, Tolstrup JS, Friberg J, Jensen G, Gronbaek M. Alcohol consumption and risk of atrial fibrillation in men and women: the Copenhagen City Heart Study. Circulation 2005;112:1736-1742.

41. Mukamal KJ, Psaty BM, Rautaharju PM, Furberg CD, Kuller LH, Mittleman MA, Gottdiener JS, Siscovick DS. Alcohol consumption and risk and prognosis of atrial fibrillation among older adults: the Cardiovascular Health Study. Am Heart J 2007; 153:260-266.

42. Mont L, Sambola A, Brugada J, Vacca M, Marrugat J, Elosua R, Pare C, Azqueta M, Sanz G. Long-lasting sport practice and lone atrial fibrillation. Eur Heart J 2002;23:477482.

43. Elosua R, Arquer A, Mont L, Sambola A, Molina L, Garcia-Moran E, Brugada J, Marrugat J. Sport practice and the risk of lone atrial fibrillation: a case-control study. Int J Cardiol 2006;108:332-337.

44. Mont L, Tamborero D, Elosua R, Molina I, Coll-Vinent B, Sitges M, Vidal B, Scalise A, Tejeira A, Berruezo A, Brugada J, the GIRAFA (Grup Integrat de Recerca en Fibril-lacio Auricular) Investigators. Physical activity, height, and left atrial size are independent risk factors for lone atrial fibrillation in middle-aged healthy individuals. Europace 2008;10:15-20.

45. Molina L, Mont L, Marrugat J, Berruezo A, Brugada J, Bruguera J, Rebato C, Elosua R. Long-term endurance sport practice increases the incidence of lone atrial fibrillation in men: a follow-up study. Europace 2008;10:618-623. 
46. Heidbuchel H, Anne W, Willems R, Adriaenssens B, van de Werf F, Ector H. Endurance sports is a risk factor for atrial fibrillation after ablation for atrial flutter. Int $\mathrm{J}$ Cardiol 2006;107:67-72.

47. Mitchell GF, Vasan RS, Keyes MJ, Parise H, Wang TJ, Larson MG, D’Agostino Sr RB, Kannel WB, Levy D, Benjamin EJ. Pulse pressure and the risk of new-onset atrial fibrillation. JAMA 2007;297:709-715.

48. Eaker ED, Sullivan LM, Kelly-Hayes M, D'Agostino Sr RB, Benjamin EJ. Anger and hostility predict the development of atrial fibrillation in men in the Framingham Offspring Study. Circulation 2004;109:1267-1271.

49. Mattioli AV, Bonatti S, Zennaro M, Mattioli G. The relationship between personality, socioeconomic factors, acute life stress and the development, spontaneous conversion and recurrences of acute lone atrial fibrillation. Europace 2005;7:211-220.

50. Fox CS, Parise H, Vasan RS, Levy D, O'Donell CJ, D'Agostino RB, Plehn JF, Benjamin EJ. Mitral annular calcification is a predictor for incident atrial fibrillation. Atherosclerosis 2004;173:291-94.

51. Lorenz MW, Marcus HS, Bots ML, Rosvall M, Sitzer M. Prediction of clinical cardiovascular events with carotid intima-media thickness. Circulation 2007;115:459467.

52. Allessie M, Ausma J, Schotten U. Electrical, contractile and structural remodeling during atrial fibrillation. Cardiovasc Res 2002;54:230-246.

53. Boos CJ, Anderson RA, Lip GYH. Is atrial fibrillation an inflammatory disorder? Eur Heart J 2006;27:136-149.

54. Sitges M, Teijeira VA, Scalise A, Vidal B, Tamborero D, Collvinent B, Rivera S, Molina I, Azqueta M, Pare C, Brugada J, Mont L. Is there an anatomical substrate for idiopathic paroxysmal atrial fibrillation? A case-control echocardiographic study. Europace 2007;9:294-298.

55. Kourliouros A, Savelieva I, Kiotsekoglou A, Jahangiri M, Camm J. Current concepts in the pathogenesis of atrial fibrillation. Am Heart J 2009;157:243-252.

56. Roberts JD, Gollob MH. Impact of genetic discoveries on the classification of lone atrial fibrillation. J Am Coll Cardiol 2010;55:705-712.

57. Schoonderwoerd BA, Smit MD, Pen L, Van Gelder IC. New risk factors for atrial fibrillation: causes of “not-so-lone atrial fibrillation'. Europace 2008;10:668-673.

58. Kozlowski D, Burdejko S, Lip GYH, Rysz J, Mikhailidis DP, Raczak G, Banach M. Lone atrial fibrillation: what do we know? Heart 2010;96:498-503.

59. Lip GYH, Nieuwlaat R, Pisters R, Lane DA, Crijns HJ. Refining clinical risk stratification for predcting stroke and thromboembolism using a novel risk factor-based approach. Chest 2010;137:263-272.

60. Levy S, Maarek M, Coumel P, Guize L, Lekieffre J, Medvedowsky J, Sebaoun A, on behalf of the College of French Cardiologists. Characterization of different subsets of atrial fibrillation in general practice in France. The ALFA Study. Circulation 1999;99:3028-3035.

61. Lloyd-Jones DM, Wang TJ, Leip EP, Larson MG, Levy D, Vasan RS, D'Agostino RB, Massaro JM, Beiser A, Wolf PA, Benjamin EJ. Lifetime risk for development of atrial fibrillation. The Framingham heart study. Circulation 2004;110:1042-6. 
62. Kannel WB, Wolf PA, Benjamin EJ, Levy D. Prevalence, incidence, prognosis, and predisposing conditions for atrial fibrillation: population based estimates. Am J Cardiol 1998; 82:2N-9N.

63. Chen LY, Herron KJ, Tai BC, Olson TM. Lone atrial fibrillation: influence of familial disease on gender predilection. J Cardiovasc Electrophysiol 2008;19:802-806.

64. Wolff L. Familial auricular fibrillation. N Engl J Med 1943;229:396-397.

65. Brugada R, Tapscott T, Czernuszewicz GZ, Marian AJ, Iglesias A, Mont L, Brugada J, Girona J, Domingo A, Bachinski LL, Roberts R. Identification of a genetic locus for familial atrial fibrillation. N Engl J Med 1997;336:905-911.

66. Ellinor PT, Shin JT, Moore RK, Yoerger DM, MacRae CA. Locus for atrial fibrillation maps to chromosome 6q14-16. Circulation 2003;107:2880-2883.

67. Chen YH, Xu SJ, Bendahlou S, Wang XL, Wang Y, Xu WY, Jin HW, Sun H, Su XY, Zhuang QN, Yang YQ, Li YB, Liu Y, Xu HJ, Li XF, Ma N, Mou CP, Chen Z, Barhanin J, Huang W. KCNQ1 gain-of-funkcion mutation in familial atrial fibrillation. Science 2003;299:251-4.

68. Oberti C, Wang L, Li L, Dong J, Rao S, Du W, Wang Q. Genome-wide linkage scan identifies a novel genetic locus on chromosome $5 \mathrm{p} 13$ for neonatal atrial fibrillation associated with sudden death and variable cardiomyopathy. Circulation 2004;110:37533759.

69. Volders PG, Zhu Q, Timmermans C, Eurlings PM, Su X, Arens YH, Li L, Jongbloed RJ, Xia M, Rodriguez LM, Chen YH. Mapping a novel locus for familial atrial fibrillation on chromosome 10p11-q21. Heart Rhythm 2007;4:469-75.

70. Yang Y, Xia M, Jin Q, Bendahhou S, Shi J, Chen Y, Liang B, Lin J, Liu Y, Liu B, Zhou Q, Zhang D, Wang R, Ma N, Su X, Niu K, Pei Y, Xu W, Chen Z, Wan H, Cui J, Barhanin J. Identification of a KCNE2 gain-of-function mutation in patients with familial atrial fibrillation. Am J Hum Genet 2004;75:899-905.

71. Olson M, Alekseev AE, Liu XK, Park S, Zingman LV, Blenengraeber M, Sattiraju S, Ballew JD, Jahangir A, Terzic A. Kv1.5 channelopathy due to KCNA5 loss-of-function mutation causes human atrial fibrillation. Hum Mol Genet 2006;15:2185-2191.

72. Darbar D, Kannankeril PJ, Donahue BS, Kucera G, Stubblefield T, Haines J, George AL Jr, Roden DM. Cardiac sodium channel (SCNA5) variants associated with atrial fibrillation. Circulation 2008;117:1927-1935.

73. Makiyama T, Akao M, Shizuta S, Doi T, Nishiyama K, Oka Y, Ohno S, Nishio Y, Tsuji $\mathrm{K}$, Itoh $\mathrm{H}$, Kimura T, Kita T, Horie M. A novel SCN5A gain-of-function mutation M1875T associated with familial atrial fibrillation. J Am Coll Cardiol 2008;52:13261234.

74. Fox CS, Parise H, D’Agostino RB, Lloyd-Jones DM, Vasan RS, Wang TJ, Levy D, Wolf PA, Benjamin EJ. Parental atrial fibrillation as a risk factor for atrial fibrillation in offspring. JAMA 2004;291:2851-1855.

75. Elinor PT, Yoerger DM, Ruskin JM, MacRae CA. Familial aggregation in lone atrial fibrillation. Hum Genet 2005;118:179-184.

76. Christophersen IE, Ravn LS, Budtz-Joergensen E, Skytthe A, Haunsoe S, Svendsen JH, Christensen K. Familial aggregation of atrial fibrillation. A Study of Danish Twins. Circ Arrhythmia Electrophysiol 2009;2:378-383. 
77. Arnar DO, Thorvaldsson S, Manolio TA, Thorgeirsson G, Kristjansson K, Hakonarson H, Stefansson K. Familial aggregation of atrial fibrillation in Iceland. Eur Heart J 2006;27:708-712.

78. Xia M, Jin Q, Bendahhaou S, He Y, Larroque MM, Chen Y, Zhou Q, Yang Y, Liu B, Zhu Q, Zhou Y, Lin J, Liang B, Li L, Dong X, Pan Z, Wang R, Wan H, Qiu W, Xu W, Eurlings P, Barhanin J. A Kir2.1 gain-of-function mutation underlies familial atrial fibrillation. Biochem Biophys Res Commun 2005;332:1012-1019.

79. Ravn LS, Aizawa Y, Pollevick GD, Hofman-Bang J, Cordeiro JM, Dixen U, Jensen G, Wu Y, Burashnikov E, Haunso S, Guerchicoff A, Hu D, Svendsen JH, Christiansen M, Antzelevitch C. Gain-of-function in $\mathrm{I}_{\mathrm{Ks}}$ secondary to a mutation in KCNE5 associated with atrial fibrillation. Heart Rhythm 2008;5:427-435.

80. Ellinor PT, Nam EG, Shea MA, Milan DJ, Ruskin JN, MacRae CA. Cardiac sodium channel mutation in atrial fibrillation. Heart Rhythm 2008;5:99-105.

81. Antzelevitch C, Pollevick GD, Cordeiro JM, Casis O, Sanguinetti MC, Aizawa Y, Guerchicoff A, Pfeiffer R, Oliva A, Wollnik B, Gelber P, Bonaros EP Jr, Burashnikov E, Wu Y, Sargent JD, Schickel S, Oberheiden R, Bhatia A, Hsu LF, Haissaguerre M, Schimpf R, Borggrefe M, Wolpert C. Loss-of-function mutations in the cardiac calcium channel underlie a new clinical entity characterized by ST-segment elevation, short QT intervals, and sudden cardiac death. Circulation 2007;115:442-449.

82. Chaldoupi SM, Loh P, Hauer RN, de Bakker JM, van Rijen HV. The role of connexin40 in atrial fibrillation. Cardiovasc Res 2009;84:15-23.

83. Sabeh MK, MacRae CA. The genetics of atrial fibrillation. Curr Opin Cardiol 2010;25:186-191.

84. Parvez B, Darbar D. Lone AF - Etiologic factors and genetic insights into pathophysiology. Journal of Atrial Fibrillation 2010;1:675-684.

85. Brauch KM, Chen LY, Olson TM. Comprehensive mutation scanning of LMNA in 268 patients with lone atrial fibrillation. Am J Cardiol 2009;103:1426-1428.

86. Yang T, Yang P, Roden DM, Darbar D. A novel KCNA5 mutation implicates tyrosine kinase signaling in human atrial fibrillation. Heart Rhythm 2010;7:1246-1252.

87. Allessie MA, Boyden PA, Camm JA, Kleber AG, Lab MJ, Legato MJ, Rosen MR, Schwartz PJ, Spooner PM, Van Wagoner DR, Waldo AL. Pathophysiology and prevention of atrial fibrillation. Circulation 2001;103:769-777.

88. Haissaguerre M, Jais P, Shah DC, Takahashi A, Hocini M, Quiniou G, Garrigue S, Le Mouroux A, Le Metayer P, Clementy J. Spontaneous initiation of atrial fibrillation by ectopic beats originating in the pulmonary veins. N Engl J Med 1998;339:659-666.

89. Wijffels MC, Kirchhof CJ, Dorland R, Allessie MA. Atrial fibrillation begets atrial fibrillation. A study in awake chronically instrumented goats. Circulation 1995;92:19541968.

90. Fynn SP, Todd DM, Hobbs WJ, Armstrong KL, Fitzpatrick AP, Garrat CJ. Clinical evaluation of a policy of early repeated internal cardioversion for reccurrence of atrial fibrillation. J Cardiovasc Electrophysiol 2002;13:135-141.

91. Garratt CJ, Duytschaever M, Killian M, Dorland R, Mast F, Allessie MA. Repetitive electrical remodeling by paroxysms of atrial fibrillation in the goat: no cumulative effect on inducibility or stability of atrial fibrillation. $J$ Cardiovasc Electrophysiol 1999;10:1101-1108. 
92. Jais P, Hocini M, MacLe L, Choi KJ, Deisenhofer I, Weerasooriya R, Shah DC, Garrigue S, Raybaud F, Scavee C, Le Metayer, Clémenty J, Haïssaguerre M. Distinctive electrophysiological properties of pulmonary veins in patients with atrial fibrillation. Circulation 2002;106:2479-2485.

93. Chen SA, Tai CT. Catheter ablation of atrial fibrillation originating from the nonpulmonary vein foci. J Cardiovasc Electrophysiol 2005;16:229-232.

94. Frustaci A, Chimenti C, Bellocci F, Morgante E, Russo MA, Maseri A. Histological substrate of atrial biopsies in patients with lone atrial fibrillation. Circulation 1997;96:1180-1184.

95. Skalidis EI, Hamilos MI, Karalis IK, Chlouverakis G, Kochiadakis GE, Vardas PE. Isolated atrial microvascular dysfunction in patients with lone recurrent atrial fibrillation. J Am Coll Cardiol 2008;51:2053-2057.

96. Stiles MK, John B, Wong CX, Kuklik P, Brooks AG, Lau DH, Dimitri H, RobertsThomson KC, Wilson L, De Sciscio P, Young GD, Sanders P. Paroxysmal lone atrial fibrillation is associated with abnormal atrial substrate. Characterizing the "Second Factor". J Am Coll Cardiol 2009;53:1182-1191.

97. Centurion OA, Isomoto S, Shimizu A. Electrophysiological changes of the atrium in patients with lone paroxysmal atrial fibrillation. Journal of Atrial Fibrillation 2010;1:656662.

98. Engelmann MDM, Svendsen JH. Inflammation in the genesis and perpetuation of atrial fibrillation. Eur Heart J 2005;26:2083-2092.

99. Patel P, Dokainish H, Tsai P, Lakkis P. Update on the association of inflammation and atrial fibrillation. J Cardiovasc Electrophysiol 2010;21:1064-1070.

100. Conway DS, Buggins P, Hughes E, Lip GY. Relationship of interleukin-6 and C-reactive protein to the prothrombotic state in chronic atrial fibrillation. J Am Coll Cardiol 2004;43:2075-2082.

101. Aviles RJ, Martin DO, Apperson-Hansen C, Houghtaling PL, Rautaharju P, Kronmal RA, Tracy RP, Van Wagoner DR, Psaty BM, Lauer MS, Chung MK. Inflammation as a risk factor for atrial fibrillation. Circulation 2003;108:3006-3010.

102. Asselbergs FW, Van Den Berg MP, Diercks GF, Van Gilst WH, Van Veldhuisen DJ. Creactive protein and microalbuminuria are associated with atrial fibrillation. Int $\mathrm{J}$ Cardiol 2005;98:73-77.

103. Hatzinikolaou-Kotsakou E, Tziakas D, Hotidis A, Stakos D, Floros D, Papanas N, Chalikias G, Maltezos E, Hatseras DI. Relation of C-reactive protein to the first onset and the recurrence rate in lone atrial fibrillation. Am J Cardiol 2006;97:659-661.

104. Kallergis EM, Manios EG, Kanoupakis EM, Mavrakis HE, Kolyvaki SG, Lyrarakis GM, Chlouverakis GI, Vardas PE. The role of the post-cardioversion time course of hs-CRP levels in clarifying the relationship between inflammation and persistence of atrial fibrillation. Heart 2008;94:200-204.

105. Marcus GM, Smith LM, Glidden DV, Wilson E, McCabe JM, Whiteman D, Tseng ZH, Badhwar N, Lee BK, Lee RJ, Scheinman MM, Olgin JE. Markers of inflammation before and after curative ablation of atrial flutter. Heart Rhythm 2008;5:215-221.

106. Ellinor PT, Low A, Patton KK, Shea MA, MacRae CA. C-reactive protein in lone atrial fibrillation. Am J Cardiol 2006;97:1346-1350. 
107. Mihm MJ, Yu F, Carnes CA, Reiser PJ, McCarthy PM, Van Wagoner DR, Bauer JA. Impaired myofibrillar energetics and oxidative injury during human atrial fibrillation. Circulation 2001;104:174-180.

108. Rossi A, Enriquez-Sarano M, Burnett JC Jr, Lerman A, Abel MD, Seward JB. Natriuretic peptide levels in atrial fibrillation: a prospective hormonal and Dopplerechocardiographic study. J Am Coll Cardiol 2000;35:1256-1262.

109. Ellinor PT, Low AF, Patton KK, Shea MA, MacRae CA. Discordant atrial natriuretic peptide and brain natriuretic peptide levels in lone atrial fibrillation. J Am Coll Cardiol 2005;45:82-86.

110. Ellinor PT, Low AF, MacRae CA. Reduced apelin levels in lone atrial fibrillation. Eur Heart J 2006;27:222-226.

111. Huang JL, Wen ZC, Lee WL, Chang MS, Chen SA. Changes of autonomic tone before the onset of paroxysmal atrial fibrillation. Int J Cardiol 1998;66:275-283.

112. Zhou J, Scherlag B, Edwards J, Jackman W, Lazarra R, Po S. Gradient of atrial refractoriness and inducibility of atrial fibrillation due to stimulation of ganglionated plexi. J Cardiovasc Electrophysiol 2007;18:83-90.

113. Hara M, Shvilkin A, Rosen MR, Danilo P Jr, Boyden PA. Steady-state and non-steadystate action potentials in fibrillating canine atrium: abnormal rate adaptation and its possible mechanisms. Cardiovasc Res 1999;42:455-469.

114. Van Wagoner DR, Pond AL, Lamorgese M, Rossie SS, McCarthy PM, Nerbonne JM. Atrial L-type $\mathrm{Ca}^{2+}$ currents and human atrial fibrillation. Circ Res 1999;85:428-436.

115. Kostin S, Klein G, Szalay Z, Hein S, Bauer EP, Schaper J. Structural correlate of atrial fibrillation in human patients. Cardiovasc Res 2002;54:361-379.

116. Polontchouk L, Haefliger JA, Ebelt B, Schaefer T, Stuhlmann D, Mehlhorn U, KuhnRegnier F, de Vivie R, Dhein S. Effects of chronic atrial fibrillation on gap junction distribution in human and rat atria. J Am Coll Cardiol 2001;38:883-891.

117. Nao T, Ohkusa T, Hisamatsu Y, Inoue N, Matsumoto T, Yamada J, Shimitzu A, Yoshiga Y, Yamagata T, Kobayashi S, Yano M, Hamano K, Matsuzaki M. Comparison of expression of connexin in right atrial myocardium in patients with chronic atrial fibrillation versus those in sinus rhythm. Am J Cardiol 2003;91:678-683.

118. Chen YJ, Chen YC, Yeh HI, Lin CI, Chen SA. Electrophysiology and arrhythmogenic activity of single cardiomyocytes from canine superior vena cava. Circulation 2002;105:2679-2685.

119. Spach MS, Kootsey JM, Sloan JD. Active modulation of electrical coupling between cardiac cells of the dog. A mechanism for transient and steady state variations in conduction velocity. Circ Res 1982;51:347-362.

120. Singh B. Atrial fibrillation: from ion channels to bedside treatment options. Journal of Electrocardiology 2009;42:660-670.

121. Van der Hooft CS, Heeringa J, van Herpen G, Kors JA, Kingma JH, Stricker BH. Druginduced atrial fibrillation. J Am Coll Cardiol 2004;44:2117-2124.

122. Katritsis DG, Toumpoulis IK, Giazitzoglou E, Korovesis S, Karabinos I, Paxinos G, Zambartas C, Anagnostopoulos CE. Latent arterial hypertension in apparently lone atrial fibrillation. J Interv Card Electrophysiol 2005;13:203-207.

123. Osranek M, Bursi F, Bailey KR, Grossardt BR, Brown RD Jr, Kopecky SL, Tsang TS, Seward JB. Left atrial volume predicts cardiovascular events in patients originally 
diagnosed with lone atrial fibrillation: three-decade follow-up. Eur Heart J 2005;26:25562561.

124. Camm JA, Kirchof P, Lip GYH, Schotten U, Savelieva I, Ernst S, Van Gelder IC, A1Attar N, Hindricks G, Prendergast B, Heidbuchel H, Alfieri O, Angelini A, Atar D, Colonna P, De Caterrina R, De Sutter J, Goette A, Gorenek B, Heldal M, Hohloser SH, Kolh P, Le Heuzey JY, Ponikowsky P, Rutten FH. Guidelines for the management of atrial fibrillation. The Task Force for the Management of Atrial Fibrillation of the European Society of Cardiology (ESC). Eur Heart J 2010;doi:10.1093/eurheartj/ehq278.

125. Sato H, Ishikawa K, Kitabatake A, Ogawa S, Maruyama Y, Yokota Y, Fukuyama T, Doi Y, Mochizuki S, Izumi T, Takekoshi N, Yoshida K, Hiramori K, Origasa H, Uchiyama S, Matsumoto M, Yamaguchi T, Hori M. Low-dose aspirin for prevention of stroke in lowrisk patients with atrial fibrillation: Japan Atrial Fibrillation Stroke Trial. Stroke 2006;37:447-451.

126. Hart RG, Pearce LA, Aguilar MI. Meta-analysis: antithrombotic therapy to prevent stroke in patients who have nonvalvular atrial fibrillation. Ann Intern Med 2007;146:857-867.

127. Freestone B, Chong AY, Nuttall S, Blann AD, Lip GYH. Soluble E-selectin, von Willebrand factor, soluble thrombomodulin, and total body nitrate/nitrite product as indices of endothelial damage/dysfunction in paroxysmal, persistent, and permanent atrial fibrillation. CHEST 2007;132:1253-1258.

128. Conolly SJ, Ezekowitz MD, Yusuf S, Eikelboom J, Oldgren J, Parekh A, Pogue J, Reilly PA, Themeles E, Varrone J, Wang S, Alings M, Xavier D, Zhu J, Diaz R, Lewis BS, Darius H, Diener HC, Joyner CD, Wallentin L. Dabigatran versus warfarin in patients with atrial fibrillation. N Engl J Med 2009;361:1139-1151.

129. Le Heuzey J, De Ferrari GM, Radzik D, Santini M, Zhu J, Davy JM. A short-term, randomized, double-blind, parallel-group study to evaluate the efficacy and safety of dronedarone versus amioadrone in patients with persistent atrial fibrillation: the DIONYSOS study. J Cardiovasc Electrophysiol 2010;21:597-605.

130. Jais P, Cauchemez B, Macle L, Daoud E, Khairy P, Subbiah R, Hocini M, Extramiana F, Sacher F, Bordachar P, Klein G, Weerasooriya R, Clementy J, Haissaguerre M. Catheter ablation versus antiarrhythmic drugs for atrial fibrillation: the A4 study. Circulation 2008;118:2498-2505.

131. Shah AN, Mittal S, Sichrovsky TC, Cotiga D, Arshad A, Maleki K, Pierce WJ, Steinberg JS. Long-term outcome following successful pulmonary vein isolation: pattern and prediction of very late recurrence. J Cardiovasc Electrophysiol 2008;19:661-667.

132. Calkins H, Reynolds MR, Spector P, Sondhi M, Xu Y, Martin A, Williams CJ, Sledge I. Treatment of arial fibrillation with antiarrhythmic drugs or radiofrequency ablation: two systematic literature reviews and meta-analyses. Circ Arrhythm Electrophysiol 2009;2:349-361.

133. De Cecco NC, Buffa V, David V, Fedeli S. Novel approaches for the surgical treatment of atrial fibrillation: time for a guideline revision? Vascular Health and Risk Management 2010;6:439-447.

134. Gaita F, Riccardi R, Caponi D, Shah D, Garberoglio L, Vivalda L, Dulio A, Chiecchio A, Manasse E, Gallotti R. Linear cryoablation of the left atrium versus pulmonary vein cryoisolation in patients with permanent atrial fibrillation and valvular heart disease: correlation of electroanatomic mapping and long-term clinical results. Circulation 2005;111:136-142. 
135. Antzelevitch C, Burashnikov A. New developments in atrial antiarrhythmic therapy. Nat Rev Cardiol 2010;7:139-148.

136. Hohnloser SH, Crijns HJ, van Eickels M, Gaudin C, Page RL, Torp-Pedersen C, Connolly SJ. Effect of dronedarone on cardiovascular events in atrial fibrillation. N Engl J Med 2009;360:668-678.

137. Singh BN, Connolly SJ, Crijns H, Roy D, Kowey PR, Capucci A, Radzik D, Aliot EM, Hohnloser SH, for the EURIDIS and ADONIS Investigators. Dronedarone for Maintenance of Sinus Rhythm in Atrial Fibrillation or Flutter. N Engl J Med 2007;357:987-999.

138. Kober L, Torp-Pedersen C, McMurray JJV, Gotzsche O, Levy S, Crijns H, Amlie J, Carlsen J, for the Dronedarone Study Group Increased Mortality after Dronedarone Therapy for Severe Heart Failure. N Engl J Med 2008;358:2678-2687.

139. Roy D, Pratt CM, Torp-Pedersen C, Wyse G, Toft E, Juul-Moller S, Nielsen T, Rasmussen SL, Stiell IG, Coutu B, Ip JH, Pritchett ELC, Camm AJ, for the Atrial Arrhythmia Conversion Trial Investigators Vernakalant Hydrochloride for Rapid Conversion of Atrial Fibrillation. A Phase 3, Randomized, Placebo-Controlled Trial. Circulation 2008;117:1518-1525.

140. Belluzzi F, Sernesi L, Preti P, Salinaro F, Fonte ML, Perlini S. Prevention of recurrent lone atrial fibrillation by the angiotensin-II converting enzyme inhibitor ramipril in normotensive patients. J Am Coll Cardiol 2009;53:24-29.

141. Disertori M, Latini R, Barlera S, Franzosi MG, Staszewsky L, Maggioni AP, Lucci D, Di Pasquale G, Tognoni G. Valsartan for prevention of recurrent atrial fibrillation. N Engl J Med 2009;360:1606-1617.

142. Liakopoulos OJ, Choi YH, Kuhn EW, Wittwer T, Borys M, Madershahian N, Wassmer G, Wahlers T. Statins for prevention of atrial fibrillation after cardiac surgery: a systematic literature review. J Thorac Cardiovasc Surg 2009;138:678-686e1.

143. Bhardway A. Sood NA, Kluger J, Coleman CI. Lack of effect of statins on maintenance of normal sinus rhythm following electrical cardioversion of persistent atrial fibrillation. Int J Clin Pract 2010;64:1116-1120. 
Table 1. The genetics of atrial fibrillation.

\begin{tabular}{|c|c|c|c|c|c|c|}
\hline & Chromosome & Gene & $\begin{array}{l}\text { Ion channel/ } \\
\text { current/other }\end{array}$ & $\begin{array}{l}\text { Electrophysiological effects of the } \\
\text { mutation }\end{array}$ & Mechanism of AF & Associated phenotype/comment \\
\hline \multirow{8}{*}{ 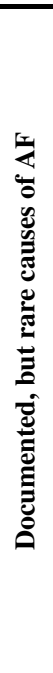 } & $\begin{array}{l}11 \mathrm{p} 15.5 \\
21 \mathrm{q} 22.1 \\
17 \mathrm{q} 23-24 \\
X \text { chrom. } \\
7 \mathrm{q} 36.1\end{array}$ & $\begin{array}{l}\text { KCNQ1 } 1^{[67]} \\
\text { KCNE2 } 2^{[70]} \\
\mathrm{KCNJ}^{[78]} \\
\mathrm{KCNE}^{[79]} \\
\mathrm{KCNH}^{[56]}\end{array}$ & $\begin{array}{l}\mathrm{I}_{\mathrm{Ks}} \\
\mathrm{I}_{\mathrm{Ks}}[\mathrm{KCNQ1-KCNE2]} \\
\mathrm{I}_{\mathrm{K} 1} \\
\mathrm{I}_{\mathrm{Ks}} \\
\mathrm{K}_{\mathrm{v}} 11.1\end{array}$ & $\begin{array}{l}\text { accelerated repolarization of atrial } \\
\text { cardiomyocytes, } \\
\text { shortening of AP duration } \\
\text { reduction of ERP }\end{array}$ & multiple reentry wavelets & $\begin{array}{l}\text { KCNQ1-causative gene for Long QT syndrome type } \\
1 \\
\text { KCNE2, KCNJ2 and KCNE5 - normal QT interval } \\
\text { KCNH2 and KCNQ1 - associated with Long QT } \\
\text { type } 2 \text { and Short QT syndrome ( } \sim 30 \% \text { of cases })\end{array}$ \\
\hline & $3 \mathrm{p} 22.2$ & $\mathrm{KCNA}^{[71]}$ & $\begin{array}{l}\mathrm{K}_{\mathrm{v}} 1.5 / \mathrm{I}_{\mathrm{Kur}} \\
\mathrm{Na}_{\mathrm{v}} 1.5\end{array}$ & $\begin{array}{c}\text { delayed atrial AP repolarization, } \\
\text { prolonged both AP duration and } \\
\text { atrial ERP } \\
\text { hyperpolarization, } \\
\text { prolonged AP duration }\end{array}$ & $\begin{array}{l}\text { early afterdepolarizations initiate } \\
\text { atrial polymorphic tachycardia } \\
\text { "torsade de pointes" which } \\
\text { degenerates to AF }\end{array}$ & $\begin{array}{l}\text { SCN5A-associated with Long QT type 3, Brugada } \\
\text { syndrome and Sick sinus syndrome }\end{array}$ \\
\hline & $12 \mathrm{p} 13.1$ & $\begin{array}{l}\text { CACNA1C, } \\
\text { CACNB2 }^{[81]}\end{array}$ & $\mathrm{I}_{\mathrm{CaL}}$ & $\begin{array}{c}\text { enhanced heterogenity of } \\
\text { repolarization }\end{array}$ & multiple reentry wavelets & $\begin{array}{l}\text { Associated both with Brugada syndrome and Short } \\
\text { QT syndrome }\end{array}$ \\
\hline & Gen. loci $^{[65-69]}$ & & & & & \\
\hline & $10 \mathrm{q} 22-24$ & unknown & $?$ & $?$ & $?$ & Overlaps with locus for DCM \\
\hline & $6 q 14-16$ & unknown & ? & ? & ? & Overlaps with locus for DCM \\
\hline & $10 \mathrm{p} 11-\mathrm{q} 21$ & unknown & ? & ? & $?$ & Unknown \\
\hline & $5 \mathrm{p} 11$ & unknown & $?$ & $?$ & $?$ & Associated with prolonged P-wave \\
\hline \multirow{7}{*}{ 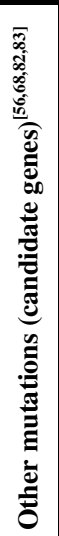 } & Chrom. 3 & SCN5A & $\mathrm{Na}_{\mathrm{v}} 1.5$ & $\begin{array}{c}\text { cell hyperexcitability } \\
\text { enhanced automaticity of } \\
\text { cardiomyocytes }\end{array}$ & $\begin{array}{l}\text { electrical reentry with "mother- } \\
\text { rotor" and spiral reentry waves }\end{array}$ & Not associated with Long QT syndrome \\
\hline & $5 \mathrm{p} 13$ & NUP155 & $\begin{array}{l}\text { Nuclear pore } \\
\text { protein }\end{array}$ & 然 & $?$ & $\begin{array}{l}\text { Associated with Emery-Dreifuss muscular } \\
\text { dystrophy syndromes }\end{array}$ \\
\hline & Chrom. 1 & GJA5 & Connexin 40 & $\begin{array}{l}\text { heterogenity of conduction velocity } \\
\text { enhanced vulnerability to electrical } \\
\text { reentry }\end{array}$ & multiple reentry wavelets & $\begin{array}{l}\text { Connexins: transmembrane proteins that form gap- } \\
\text { junctions (intercellular pores) which serve as low- } \\
\text { resistance conduction pathways between adjacent } \\
\text { cells }\end{array}$ \\
\hline & 1p36-p35 & NPPA & ANP & $\begin{array}{c}\text { shortening of atrial AP, reduction of } \\
\text { ERP }\end{array}$ & multiple reentry wavelets (in vitro) & $\begin{array}{l}\text { As a mediator of inflammation, ANP may cause } \\
\text { atrial fibrosis }\end{array}$ \\
\hline & $4 q 25$ & PITX2 & RAAS (?) & 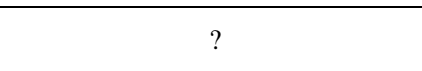 & $?$ & $\begin{array}{l}\text { Suppresses pacemaker cells from forming outside } \\
\text { the sinus node during cardiogenesis }\end{array}$ \\
\hline & $16 \mathrm{q} 22$ & ZFHX3 & $?$ & $?$ & $?$ & $\begin{array}{l}\text { Associated with both ischemic and cardioembolic } \\
\text { strokes }\end{array}$ \\
\hline & $1 \mathrm{q} 21$ & KCNN3 & ? & ? & ? & - \\
\hline
\end{tabular}

$\mathrm{AF}=$ atrial fibrillation, $\mathrm{AP}=$ action potential, $\mathrm{ERP}=$ effective refractory period, $\mathrm{DCM}=$ dilated cardiomyopathy, $\mathrm{ANP}=$ atrial natriuretic peptide, RAAS=rennin-angiotensin-aldosterone system. 
Figure 1. Pathophysiology of Atrial Fibrillation.

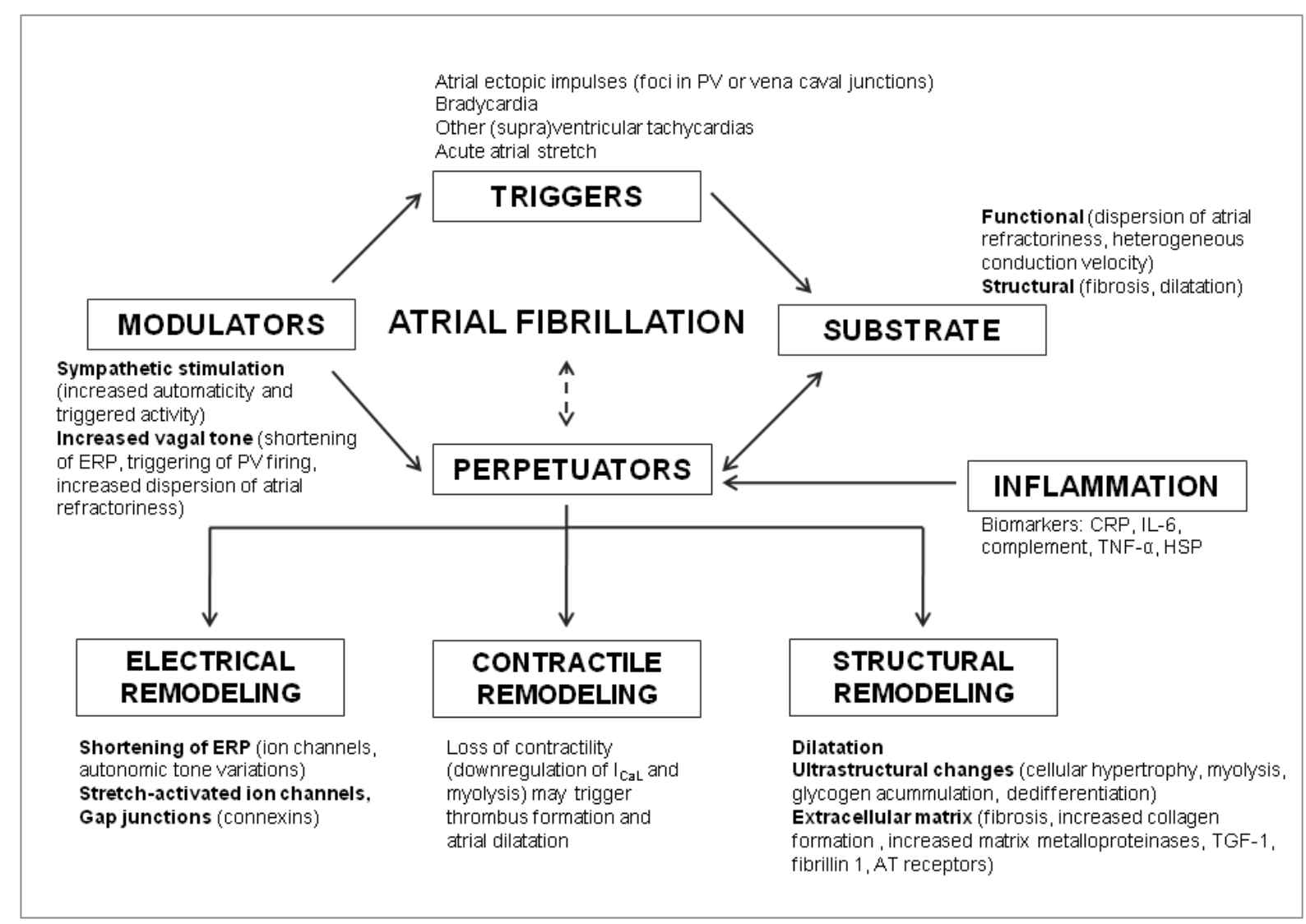

$\mathrm{PV}=$ pulmonary veins, $\mathrm{ERP}=$ effective refractory period, $\mathrm{CRP}=\mathrm{C}$-reactive protein . 
Figure 2. Clinical types of Atrial Fibrillation.

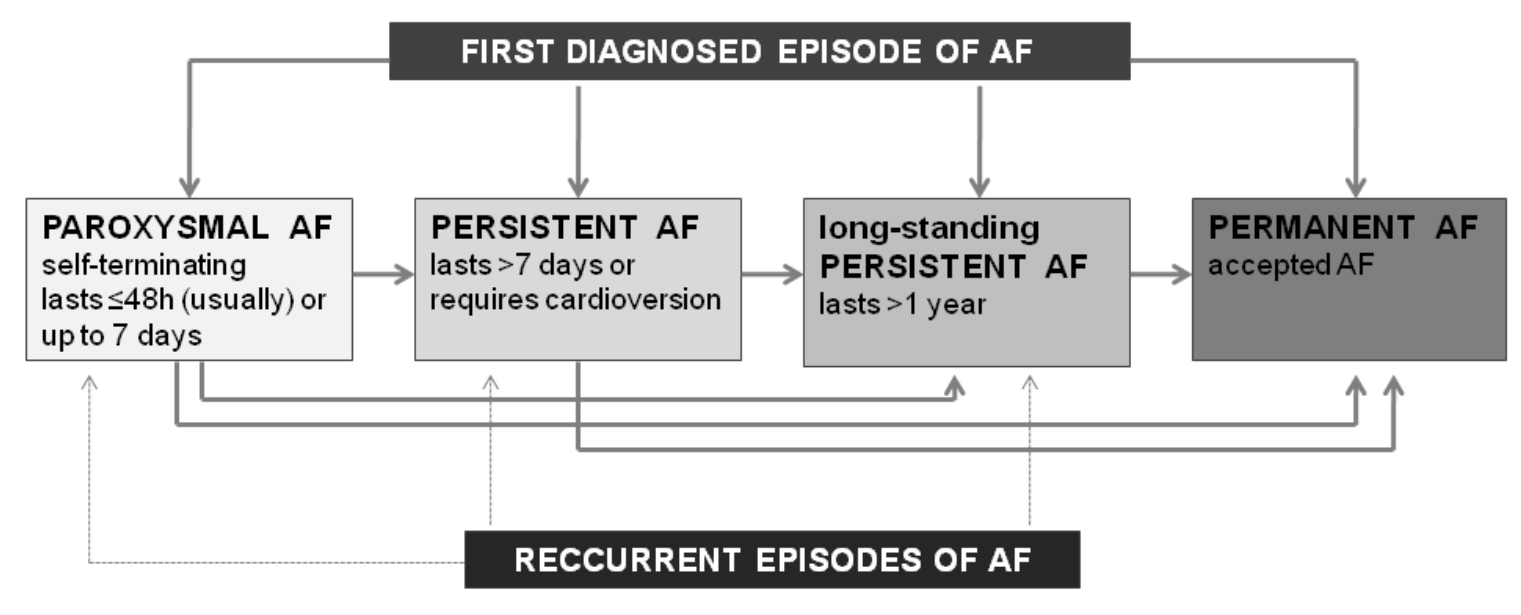

$\mathrm{AF}=\mathrm{at}$

rial fibrillation.

Modified from Camm AJ, et al. [124]. 
Figure 3. Management of Atrial Fibrillation.

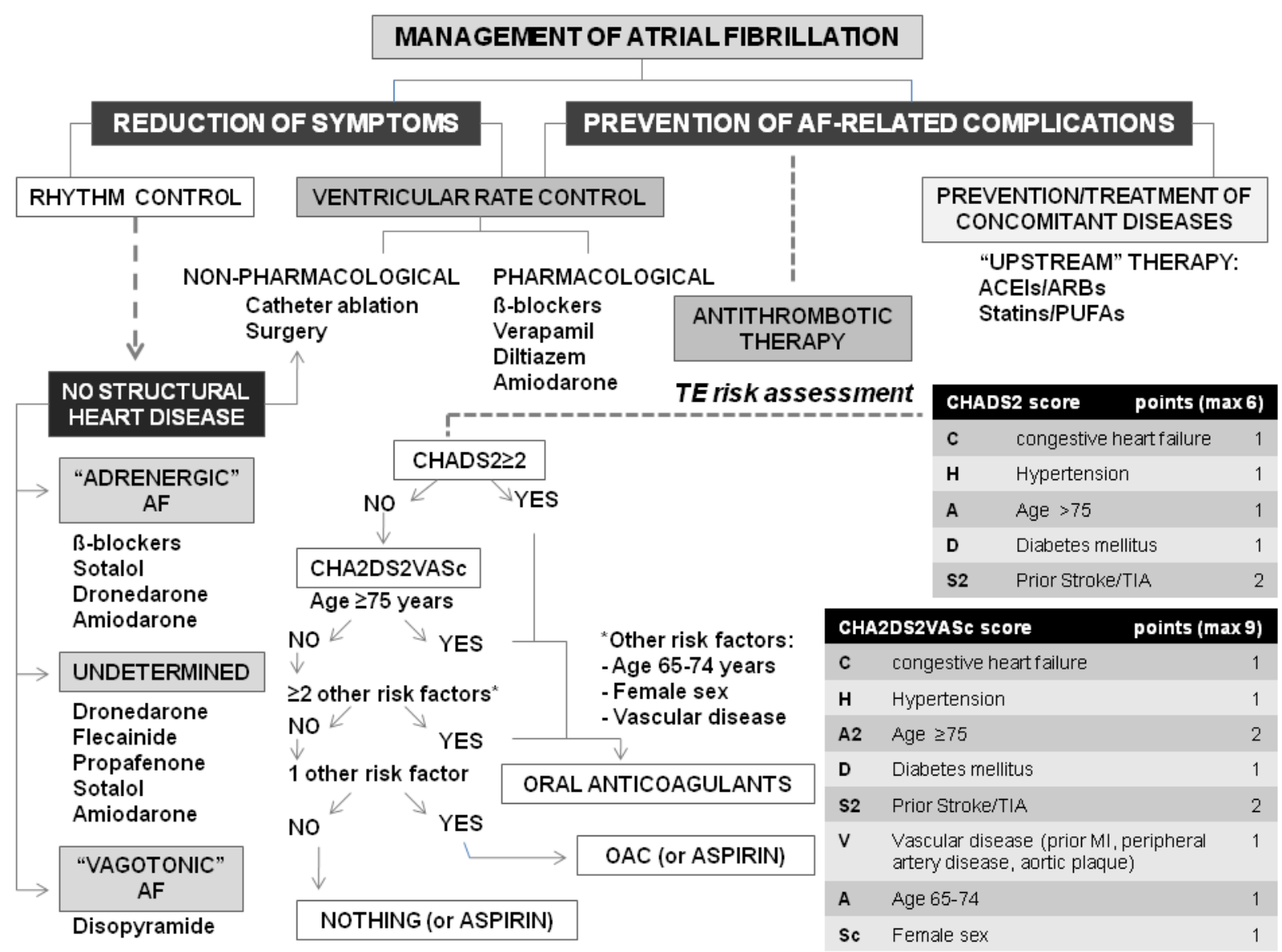

$\mathrm{AF}=$ atrial fibrillation, $\mathrm{ACEI}=$ angiotensin-converting-enzyme inhibitor, $\mathrm{ARB}=$ angitensinreceptor blocker, PUFA=polyunsaturated fatty acid, TE=thromboembolism.

Modified from Camm AJ, et al. [124]. 